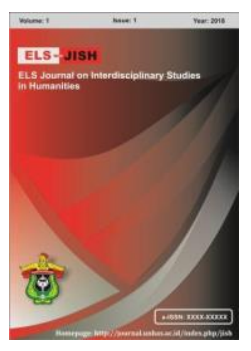

ELS-JISH

ELS Journal on Interdisciplinary Studies on Humanities

Volume 2 Issue 1, 2019

ISSN (print) : 2621-0843

ISSN (online) : 2621-0835

Homepage : http://journal.unhas.ac.id/index.php/jish

\title{
A Design of English Immersion Camp for Supplementing English Teaching and Learning in Indonesia
}

\author{
Ummu Syahidah ${ }^{1}$, Faujia Umasugi², Zakiah Buamona ${ }^{3}$ \\ 1ummusyahidah arb@gmail.com
}

\begin{abstract}
The primary purpose of this study is to design a supplementary English learning program for English students in Muhammadiyah University of North Maluku called UMMU English Immersion Camp (UEIC). Three kinds of instruments were used to gather the data, which encompassed open-ended questionnaire, UEIC observations, and interviews. To design the program, data from questionnaire were obtained from the participants which was part of Needs Analysis before conducting the UEIC. Observations and Interviews were done during the UEIC. The Results conveyed that The UEIC participants needed English learning programs that can develop and improve their ability to communicate in English confidently and in the right way. The UEIC design tried to cover the participants' needs by fomulating an English learning program where the goal was "to develop participants' communicative competence". The objectives were (1) to provide English environment where participants can practice their English ability in context, (2) to trigger participants to be more active and be confident in expressing their thought using English, and (3) to create participants' togetherness and stimulate participants ability to work in group.
\end{abstract}

Keywords: UMMU English Immersion Camp, A Design of Supplementary English Learning Program, Communicative Competence

How to cite: Syahidah U, Umasugi F \& Buamona Z. (2019). A Design of English Immersion Camp for Supplementing English Teaching and Learning in Indonesia. ELS Journal on Interdisciplinary Studies in Humanities, 2(1), 102-109.

\section{Introduction}

Every non-native-English-country has its own obstacles in dealing with finding appropriate methods for teaching and learning English. Indonesia is not an exception. For years, after English has been decided as an official foreign language to teach at formal schools, Indonesian education curriculum keeps changing. This curriculum changing automatically affects the methods of teaching and learning English at schools. One effect of the curriculum changings is time allocation for implementing English teaching and learning. In accordance with that, Hamied (2010) states that in Indonesia English is offered for six years in a strech breaking down into 4 lessons a week at most junior high schools; each lesson takes 45 minutes, and the same 4 lessons in most senior high schools. From Hamied's statement, it is seen that of 24 hours of living in a day, of 168 hours of living in a week, for six years, English learners only have three hours used for learning English in a

\footnotetext{
${ }^{1}$ English Department of Muhammadiyah University of North Maluku, Indonesia
} 
week. The time allocation for learning English is too limited for gaining better English improvement in short learners' given years.

Regarding the time allocation, there is an opinion that the limitation of time for Indonesian learners to learn English at schools is due to the status of English in Indonesia. According to Musthafa (2001) and Hamied (2010), in Indonesia, English is not considered as a Second Language (ESL), but Foreign Language (EFL). "English is not and will never be a social language nor the second official language in Indonesia". This means that English is not used as an official language for instructions in government and society life circle. Therefore, since English is considered as a foreign language, the use of it in the society daily life is limited as well. However, for Indonesian people who expect to improve their English for academic demands, it is necessary for them to get some more time than that of being given in the schools.

Besides the time, one other problem of English teaching and learning in Indonesia is the limit of English environment available. Since English is only compulsory to be taught at formal schools, after going home, Indonesian learners have no contact to English anymore. This condition contributes to their slower improvement of English.

Therefore, as an attempt to minimize these obstacles of teaching and learning English in Indonesia, supplementary English programs should be presented. One of which is a program called English Immersion Camp (IEC). EIC is an English learning program where language learners are totally surrounded or immersed by the language they are learning (FPHLCC Language Program Handbook Development Team, 2010). In EIC, learners gather together in one place and stay for a while in a tent. During EIC, learners are expected to do some activities in which the instructions are delivered in English. EIC is considered effective to help English learners to develop their English proficiency because immersion is a method of learning a language. Several studies from different countries have reported the effectiveness of immersion program such as Sangvatanachai in Thailand (2013); Luan and Guo in China (2011); Huguat, Lasagabastar, and Vila in Spain (2008); Harris in Ireland (2007); Clark in California (2000); Bostwick in Japan (1999); Buss and Lauren in Sweden (1995).

To present the EIC in Indonesia, there should be a design of its program since there are so many activities that can be included in EIC. However, there is a gap going into surface that not all of those are significantly effective to the learners English improvement. Thus, this study is going to be conducted in order to fill the gap by focusing on Indonesian learners in North Maluku Province where this study took place.

\section{Method}

In this study, descriptive qualitative was applied to identify the needs of English learners regarding the expected activities of English Immersion Camp (EIC) and the analysis of EIC characteristics. The results of needs analysis and the analysis of EIC characteristics were then formulated into a design of English Immersion Camp program called Ummu English Immersion Camp (UEIC). For this study, EIC was conducted in three days and two nights, from September 7-9 2018. The participants of this study were the members of English Department Students Association (EDSA) which were the third semester English students at Muhammadiyah University of North Maluku. Third semester students were chosen because they were still learning English and they needed some 
supplementary English activities to help them enhancing their English ability.

This study used two ways for collecting data in order to answer the research question. Nevertheless, before going through these two data collection techniques, this study used open-ended questionnaire first to conduct needs analysis to the participants in order to gather their needs and the analysis of EIC characteristics based on the questionnaire result to formulate of UEIC design for the camp. Afterward, by providing observation, the researcher observed the EIC situation including learners' attitude, learners' English acquisition development through the criteria of The Stages of English Language Acquisition Proposed by Goldberg (2000). Semi-structured of open-ended questions for interview were also used in order to get indepth infromation about learners' opinions on the program and their self-assessment on their English ability improvement. Interviews were carried out in English through an activity of EIC called "Words for UEIC".

\section{Results and Discussions}

As it has been clearly stated at the previous chapters that the main purposes of this study are to identify the needs of English of English students of Muhammadiyah University of North Maluku and to propose a design of syllabus that is expected to meet their needs, this section presents data from questionnaire. Data from questionnare were used to portray at least three parts. Firstly, it portrayed students' goals of participating into English learning program. Secondly, it described the methods or learning strategies that the students expected to have in their English learning program. And lastly, it explained the students' perspectives on how English skills and elements should be provided in an English learning program.

Based on the data from questionnaire filled by 20 students, it was found that all students needed the mastery of English allowing them to communicate in English confidently and in the right way. Two of the students wrote their goals as follow:

I want to be able to communicate with strangers [foreigners] and want to go abroad. It is one of my dream. (Student 1)

Because English is an international language or language all over the world. So when we are where the world we don't find it difficult to communicate with each other. (Student 2)

Taking these students' words into consideration, it was expected that an English program should contain the needs into a design of the program. This is in line with Hutchinson and Waters (1987), Brown (1995), Dudley-Evans and St. John (1998), Jordan (2009), Richards (2002), and Songori (2008) who state that putting the needs of learners is prominent to address because needs analysis is a key feature in the first stage of developing a language course.

After the students' needs on the goals, the questionnaire data explained that in a English language program, all students expected to be part of activities where they could be actively involved. Some of them mentioned to live in a place with a majority of English, to get used to practice English everyday with friends, to listen to English songs to practice their listening comprehension and pronunciation, to apply memorization, and many other activities that generally implied similar expectations as representatively stated by their friends. These students' expectations were also found in the English immersion program in 
which Luan and Guo (2011) state that in an immersion program, learners are immersed in target language environment for which all the time the language learners are only allowed to speak the target language. Since the students were only allowed to speak in target language which was English, they then could practice their English skills more because they had friends to practice with and the environment that supported their needs.

Regarding the students' perspectives on learning English skills and elements, data from questionnaire clearly showed that the learning process of listening, speaking, reading, writing, vocabulary, and grammar should provide a lot of time for practice. For listening skill, they expected to listen to English songs, videos, movies, and native speakers' speakings. As for mastering speaking skill, they conveyed that it was highly connected to vocabulary mastery by which the vocabularies they have tried to memorize would store into their mind just after they used those vocabularies on speaking practices. One student said,

In my opinion, to learn speaking well just by continuing to speak to friends then a lot of vocabulary is owned, it's very easy and fluent in English.

In the meantime, the students argued that grammar, reading and writing were intertwined to each other because in order to write well, they had acquire the grammar rules and had to read a lot of books, articles, newspapers, and other kinds of texts. Two students commented:

I think to learning of writing relationship to grammar because if we want to write, we have to know grammar.

In my opinion, to learn writing well just by continuing to write something then read something written and pay attention to the grammar.

Based on the data gathered from questionnaire, it was seen that all students needed to have supplementary English learning program besides their learning activities in the classroom which could cover all of their needs. A supplementary English learning program that the students expected to have could be provided by an immersion program called English Immersion Camp (EIC) because Clark (2000) points out that the characteristics of EIC utilizes the target language for most instruction and learning, features specialized groupings of new learners away from native speakers, maximizes the amount of understandable instruction in the new language, seeks to accelerate language learning by increasing time on task, and the instruction is geared to the students' developing language level.

After dealing with results of needs analysis and portraying the connection between the results of needs analysis and EIC characteristics, the students needed the mastery of English allowing them to communicate in English confidently and in the right way, the goal, objectives, materials chosen, learning strategies, assessment, and evaluation were formulated into the following table:

\section{UMMU ENGLISH IMMERSION CAMP (UEIC)}

\begin{tabular}{ccc}
\hline & \multicolumn{2}{c}{ UMMU ENGLISH IMMERSION CAMP (UEIC) } \\
\hline \multicolumn{1}{c}{ Goal } & \multicolumn{1}{c}{ Developing the Participants' Communicative Competence } \\
\hline \multirow{2}{*}{ Objectives } & 1. & To provide English environment where participants can practice their English ability in context \\
& 2. & To trigger participants to be more active and be confident in expressing their thought using English \\
\hline ELS Journal on Interdisciplinary Studies in Humanities & To create participants' togetherness and stimulate participants ability to work in group \\
\hline 3.
\end{tabular}


ISSN: (E) 2621-0835, (P) 2621-0843

\begin{tabular}{|c|c|c|c|c|c|c|c|}
\hline Materials & Intronight & $\begin{array}{c}\text { Searching } \\
\text { for Treasure }\end{array}$ & $\begin{array}{c}\text { Argument } \\
\text { Battle }\end{array}$ & Bucket Story & $\begin{array}{l}\text { Harmony } \\
\text { Night }\end{array}$ & Spelling Bee & $\begin{array}{l}\text { Words for } \\
\text { UEIC }\end{array}$ \\
\hline $\begin{array}{l}\text { Learning } \\
\text { Strategies }\end{array}$ & $\begin{array}{l}\text { Introducing } \\
\text { each } \\
\text { participant in } \\
\text { creative way. } \\
\text { Here, each } \\
\text { participant is } \\
\text { invited to } \\
\text { come in front } \\
\text { of other } \\
\text { participants } \\
\text { and } \\
\text { describes } \\
\text { one of his/ } \\
\text { her friend } \\
\text { among all } \\
\text { participants. } \\
\text { The } \\
\text { description } \\
\text { cannot } \\
\text { mention the } \\
\text { name of the } \\
\text { participant } \\
\text { he/ she } \\
\text { refers to. } \\
\text { Other } \\
\text { participants } \\
\text { have to } \\
\text { guess the } \\
\text { name of the } \\
\text { participant } \\
\text { being } \\
\text { described. } \\
\text { Participant } \\
\text { who is able } \\
\text { to guess } \\
\text { correctly, will } \\
\text { get a star as } \\
\text { the score. }\end{array}$ & $\begin{array}{l}\text { Facilitators } \\
\text { prepare six } \\
\text { papers for } \\
\text { each group } \\
\text { with some } \\
\text { short writings } \\
\text { on the front } \\
\text { side of the } \\
\text { papers. The } \\
\text { short writings } \\
\text { are parts of a } \\
\text { complete } \\
\text { sentence, } \\
\text { but those } \\
\text { parts aren't } \\
\text { written in } \\
\text { good } \\
\text { arrangement } \\
\text { at the } \\
\text { papers. The } \\
\text { facilitators } \\
\text { then put the } \\
\text { papers into } \\
\text { hidden in } \\
\text { three } \\
\text { different } \\
\text { buildings } \\
\text { around the } \\
\text { campus. } \\
\text { Each group } \\
\text { has to } \\
\text { search all } \\
\text { parts of the } \\
\text { papers. At } \\
\text { the back side } \\
\text { of the } \\
\text { papers, the } \\
\text { facilitators } \\
\text { write some } \\
\text { directions so } \\
\text { that by } \\
\text { following the } \\
\text { directions } \\
\text { participants } \\
\text { can find out } \\
\text { all the } \\
\text { papers being } \\
\text { hidden. After } \\
\text { all papers } \\
\text { are } \\
\text { gathered, } \\
\text { partcipants } \\
\text { in each } \\
\text { group have } \\
\text { to arrange } \\
\text { the papers } \\
\text { into a right } \\
\text { arrangement } \\
\text { of a } \\
\text { complete } \\
\text { sentence. } \\
\text { After that, } \\
\text { the group } \\
\text { has to } \\
\text { express their } \\
\text { opinion } \\
\text { about the } \\
\text { sentence } \\
\text { they have } \\
\text { arranged. }\end{array}$ & $\begin{array}{l}\text { Taking British } \\
\text { Parliamentary } \\
\text { Debating } \\
\text { System into } \\
\text { reference, this } \\
\text { activity is } \\
\text { designed. } \\
\text { There is no } \\
\text { quite } \\
\text { difference } \\
\text { between } \\
\text { BPDS and } \\
\text { Argument } \\
\text { Battle. This } \\
\text { activity is } \\
\text { done as an } \\
\text { intoductory } \\
\text { section for all } \\
\text { participants } \\
\text { who will take } \\
\text { Advanced } \\
\text { Speaking } \\
\text { class at their } \\
\text { following } \\
\text { semester in } \\
\text { which BPDS } \\
\text { is applied in } \\
\text { the } \\
\text { classroom. }\end{array}$ & $\begin{array}{l}\text { Facilitators } \\
\text { prepare } \\
\text { some words } \\
\text { in small } \\
\text { papers } \\
\text { based on the } \\
\text { number of } \\
\text { participants. } \\
\text { Each paper } \\
\text { contains one } \\
\text { English } \\
\text { word. The } \\
\text { papers are } \\
\text { folded and } \\
\text { all put in a } \\
\text { bucket. All } \\
\text { participants } \\
\text { are invited in } \\
\text { front of their } \\
\text { friends and } \\
\text { randomly } \\
\text { take out a } \\
\text { folded paper } \\
\text { from the } \\
\text { bucket. He/ } \\
\text { She has to } \\
\text { tell a story } \\
\text { based on the } \\
\text { word he/ she } \\
\text { gets. The } \\
\text { story has to } \\
\text { be delivered } \\
\text { al least three } \\
\text { minutes. } \\
\text { Less than } \\
\text { three } \\
\text { minutes is } \\
\text { not allowed. }\end{array}$ & $\begin{array}{l}\text { Each group } \\
\text { choose one } \\
\text { English song } \\
\text { to sing in front } \\
\text { of their friends. } \\
\text { All participants } \\
\text { sing the songs } \\
\text { together. After } \\
\text { singing, other } \\
\text { groups have to } \\
\text { explain the } \\
\text { meaning of the } \\
\text { song based on } \\
\text { their } \\
\text { understanding } \\
\text { and with their } \\
\text { own words. }\end{array}$ & $\begin{array}{l}\text { This activity } \\
\text { is like } \\
\text { Spelling Bee } \\
\text { which we } \\
\text { have already } \\
\text { know. } \\
\text { Facilitators } \\
\text { prepare } \\
\text { some words } \\
\text { and throw } \\
\text { each word to } \\
\text { participants. } \\
\text { Participants } \\
\text { have to } \\
\text { compete } \\
\text { raising their } \\
\text { hand as fast } \\
\text { as possible } \\
\text { to get } \\
\text { pointed by } \\
\text { the } \\
\text { facilitators. } \\
\text { The fastest } \\
\text { participant } \\
\text { will get } \\
\text { chance to } \\
\text { spell the } \\
\text { word. The } \\
\text { correct } \\
\text { spelling will } \\
\text { get a star as } \\
\text { the } \\
\text { additional } \\
\text { group score } \\
\text { and the } \\
\text { wrong } \\
\text { spelling will } \\
\text { loss one star } \\
\text { from their } \\
\text { group board. }\end{array}$ & $\begin{array}{l}\text { The last } \\
\text { activity } \\
\text { provides time } \\
\text { for all } \\
\text { participants } \\
\text { to share their } \\
\text { opinion about } \\
\text { all UEIC } \\
\text { activities they } \\
\text { have } \\
\text { participated. } \\
\text { The opinion } \\
\text { includes the } \\
\text { participants' } \\
\text { whetrher } \\
\text { appreciations } \\
\text { or critics. }\end{array}$ \\
\hline
\end{tabular}




\begin{tabular}{|c|c|c|c|c|c|c|c|}
\hline Assessment & $\begin{array}{l}\text { Observation: } \\
\text { Speaking, } \\
\text { Listening, } \\
\text { Vocabulary, } \\
\text { and } \\
\text { Grammar. }\end{array}$ & $\begin{array}{l}\text { Observation: } \\
\text { Reading, } \\
\text { Vocabulary, } \\
\text { Grammar, } \\
\text { and } \\
\text { Speaking. }\end{array}$ & $\begin{array}{l}\text { Observation: } \\
\text { Vocabulary, } \\
\text { Grammar, } \\
\text { Speaking, and } \\
\text { Listening. }\end{array}$ & $\begin{array}{l}\text { Observation: } \\
\text { Speaking, } \\
\text { Listening, } \\
\text { Vocabulary, } \\
\text { and } \\
\text { Grammar. }\end{array}$ & $\begin{array}{l}\text { Observation: } \\
\text { Listening, } \\
\text { Speaking, } \\
\text { Vocabulary, } \\
\text { and Grammar. }\end{array}$ & $\begin{array}{l}\text { Observation: } \\
\text { Listening } \\
\text { and } \\
\text { Vocabulary. }\end{array}$ & $\begin{array}{l}\text { Observation: } \\
\text { Speaking, } \\
\text { Vocabulary, } \\
\text { and } \\
\text { Grammar. }\end{array}$ \\
\hline
\end{tabular}

Evaluation The Stages of English Language Acquisition Proposed by Goldberg (2000)

For the design of UEIC syllabus, after conducting needs analysis the goal was formulated as an umbrella to formulate the objectives, content of learning materials, the learning strategies, assessment, and evaluation. As Richards (2002: 120) states that goals are the expected outcomes of a curriculum referring to general purpose of a language program or course. On the other hands, objectives are the expected outcomes of a syllabus. Of the goal "Developing the Participants' Communicative Competence", the objectives then were fomulated to hit the goal namely "(1) To provide English environment where participants can practice their English ability in context, (2) To trigger participants to be more active and be confident in expressing their thought using English, and (3) To create participants' togetherness and stimulate participants ability to work in group." These objectives were also the foundation to decide what kinds of materials to apply.

There were seven kinds of materials and learning strategies formulated in this design. These materials were decided based on the results of needs analysis, the goal, and the objectives which imply the focus of the materials have to deal with fulfilling the participants' needs in developing their communicative competence. Therefore, as we analyze the most materials chosen and the learning strategies, they focused on the development of participants' oral skills including speaking and listening skills as well as grammar and vocabulary mastery.

Meanwhile, as for assessment and evaluation, we mostly used observation with the critera proposed by Goldberg (2000). Assessment and evaluation was different as Nation and Macalister (2010: 107) state that assessment provide pictures of teaching and learning information regarding the learners' present knowledge and progress during the teaching and learning process. While evaluation deals with a procedure of collecting and analyze information and data from the results of assessment and monitoring in order to assess and monitor the improvement or effectiveness of a curriculum or a learning program (Brown, 1995). Brown then continues that evaluation can be done through qualitative nature including interviews, case study, classroom observations, meetings, diaries, or even conversations over coffee. Therefore, in this study assessment was done during the process of UEIC and evaluation was administered after the whole processes of UIEC had finished.

Following the design of EUIC syllabus at the table above, we can describe that in this study, UEIC was conducted in three days, from September 7 to September 9 at the Rectorate Park of UMMU. Of twenty students who collected the questionnaire, only 18 of them participated in UEIC. These 18 participants were divided into three groups namely Los Angeles, Washinngton, and Oxford. Besides participants, 6 facilitators also participated. The facilitators were 5th semester English students. Every two facilitators were in charge of one group.

During the UEIC, the facilitators designed UEIC zone where only English was allowed to use as the instructions. The tents used at the camp were five tents and set up in the UEIC zone. The UEIC zone was set up by making rope fence around the zone. For 
those who entered the UEIC zone could not use any other language except English. Participants who were found using other languages, would loss their star(s) from their group star board. Besides main activities, all supporting activities such as making food, religious activity, dinner, getting ready for praying, free time, morning exercise were also done by applying English as instructions.

In the camp, each group had a star board prepared by the facilitators where the participants scores of achievement were put. As each member of the group made mistake during the activities, like expressing the wrong answer given by facilitators, the facilitators would automatically drop the star(s) from the group star board. This was applied until the end of UEIC. Before closing the UEIC, the facilitators announced the group winner which collected the highest numbers of stars on the board. The group winner went to Los Angeles.

\section{Conclusion}

Based on the research results, it is concluded that The UEIC participants needed English learning programs that can develop and improve their ability to communicate in English confidently and in the right way. The UEIC design tried to cover the participants' needs by fomulating an English learning program where the goal was "to develop participants' communicative competence". The objectives were (1) to provide English environment where participants can practice their English ability in context, (2) to trigger participants to be more active and be confident in expressing their thought using English, and (3) to create participants' togetherness and stimulate participants ability to work in group.

\section{Acknowledgments}

This work would not have been possible without the financial support of university research program for lecturers in Muhammadiyah University of North Maluku 2018.

\section{References}

Bostwick, R. M. (1999). A study of an elementary English language immersion school in Japan. Unpublished Doctoral dissertation, Temple University, Philadelphia.

Brown, J. D. (1995). The Elements of Language Curriculum. Boston: Mass. Heinle \& Heinle Publishers.

Buss, M., \& Laurén, C. (1995). Language immersion: Teaching and second language acquisition: From Canada to Europe. Proceedings of the University of Vaasa Research Papers. Tutkimuksia No. 192. Vaasa: University of Vaasa.

Clark, K. (2000). The Design and Implementation of an English Immersion Program. In The ABC's of English Immersion, A Teacher's Guide. Washington: Center for Equal Opportunity.

Dudleay-Evans, T, \& St. John, M. J. (1998). Development in English for Specific Purposes: A Multi-Disciplinary Approach. Cambridge: Cambridge University Press.

FPHLCC Language Program Handbook Development Team. (2010). An Immersion Handbook. Brentwood Bay: First Peoples' Heritage, Language and Culture Council. Available online at www.fpcc.ca/files/PDF/culture-camps-handbook.pdf

Goldberg, A. (2000). English Immersion for All Grades. In The ABC's of English Immersion, A Teacher's Guide. Washington: Center for Equal Opportunity. 
Hamied, F.A. (2010). EFL Assessment in Indonesia: National Exams and Quality Education. In Moon and Spolsky (Eds.) Language Assessment in Asia: Local, Regional or Global?. Seoul: Asia TEFL.

Harris, J. (2007). Bilingual education and bilingualism in Ireland North and South. International Journal of Bilingual Education and Bilingualism, 10, 359-368.

Huguet, A., Lasagabaster, D., \& Vila, I. (2008). Bilingual education in Spain: Present realities and future challenges. In J. Cummins \& N. H. Hornberger (Eds.), Encyclopedia of Language and Education, 2nd Edition, Volume 5: Bilingual Education. (pp. 225-237). New York: Springer Science + Business Media LLC.

Hutchinson, T. \& Waters, A. (1987). English for Specific Purposes: A Learning-centered Approach. Cambridge: Cambridge University Press.

Jordan, R. R. (2009). English for Academic Purposes: A Guide Book for English Teachers. Cambridge: Cambridge University Press

Luan, Y. \& Guo, X. (2011). A Study on the Application of the Immersion Teaching Model to EFL Learners in Institutions of Higher Education. Canadian Center of Science and Education, 4 (1), 152-161.

Musthafa, B. (2001). English Teaching in Indonesia: Status, Issues and Challenges. An Online Article Available on http://www.oocities.org/upis3/bm/english-teaching-inindonesia.htm. Retrieved on April 15, 2018.

Nation, P. \& Macalister, J. (2010). Language Curriculum Design. New York: Routledge.

Richards, J. C. (2002). Curriculum Development in Language Teaching. The United States of America: Cambridge University Press.

Sangvatanachai, W. (2013). Response-stimulating English camp activities. In FLLT Conference Proceedings by LITU.Volume 2 Issue, 11 May 2013 Language Institute, Thammasat University, Bangkok, Thailand. (pp. 463-470). Bangkok: Language Institute, Thammasat University.

Songori, M. H. (2008). Introduction to Needs Analysis. English for Specific Purposes World, Issue 4. 